\title{
Chemically Modified Electrodes Based on 4-(azulen-1-yl)-2,6-bis ((e)-2-(thiophen-2-yl)vinyl) Pyrylium Perchlorate
}

\author{
IOANA-GEORGIANA BUGEAN ${ }^{1}$, ADINUTA PAUN ${ }^{1}$, ELENA DIACU ${ }^{1 *}$, \\ MIHAELA CRISTEA ${ }^{2}$, LIVIU BIRZAN $^{2}$, ELEONORA-MIHAELA UNGUREANU ${ }^{1}$ \\ ${ }^{1}$ University Politehnica of Bucharest, Faculty of Applied Chemistry and Material Sciences, 1-7 Polizu Str., 011061, \\ Bucharest, Romania \\ ${ }^{2}$ Institute of Organic Chemistry "C.D. Nenitzescu” of Romanian Academy, 202b Splaiul Independentei, 060023, Bucharest, \\ Romania
}

\begin{abstract}
The electrochemical behavior of 4-(azulen-1-yl)-2,6-bis((E)-2-(thiophen-2-yl)vinyl) pyrylium perchlorate $(\boldsymbol{L})$ was studied by cyclic voltammetry, differential pulse voltammetry, and rotating disk electrode voltammetry. The electrochemical polymerization of $\boldsymbol{L}$ was studied. Modified electrodes covered by polyL films were obtained by successive scanning or by controlled potential electrolysis (CPE) at different charges and potentials. The new electrodes obtained by CPE were applied for sensing the following heavy metals ions: $\mathrm{Cu}(\mathrm{II}), \mathrm{Pb}(\mathrm{II}), \mathrm{Cd}(\mathrm{II}), \mathrm{Hg}(\mathrm{II})$. The best results have been registered for $\mathrm{Pb}(\mathrm{II})$ ion with a detection limit of $10^{-8} \mathrm{M}$.
\end{abstract}

Keywords: 4-(azulen-1-yl)-2,6-bis((E)-2-(thiophen-2-yl)vinyl) pyrylium perchlorate, electrochemical methods, modified electrodes, sensing the heavy metals

\section{Introduction}

The characterization of azulen-1-yl substituted heterocycles is an important task for researchers in view of new applications. The features of such compounds are due to this double "push-pull" structure: of the azulene itself (1) and of the (2-(thiophen-2-yl)vinyl) pyrylium connected to azulene (2) where azulene is the electron donor group, and the heterocycle is the acceptor group. Azulene polarized structure may involve the compounds in both oxidation and reduction processes. The electrochemical properties (potentials values and redox waves number) are greatly influenced by the nature and position of substituents [1-5]. Determination of azulen-1-yl substituted heterocycles properties is important for the potential application of such compounds in many fields: nonlinear optics [6], organic field-effect transistors [7, 8], solar cells $[9,10]$, and molecular devices [11]. The charged pyrylium ring and the pyridinium heteroaromatic ring have a good electron donor on azulene-1-yl moiety, and increase the stability of the conjugated system, giving valuable push-pull features to the compound. Several similar compounds have been examined and found as good ligands for metal ions detection [12-14], precatalysts used for direct oxidation of amines to nitriles [15] and for the preparation of modified electrodes [1619].

This work proposes a new modified electrode based on azulene-thiophene vinyl pyrylium salt (4(azulen-1-yl)-2,6-bis((E)-2-(thiophen-2-yl)vinyl)) (Figure 1). It gives the results for sensing the following heavy metal cations: $\mathrm{Cu}(\mathrm{II}), \mathrm{Pb}(\mathrm{II}), \mathrm{Cd}(\mathrm{II})$ and $\mathrm{Hg}(\mathrm{II})$.

The study of 4-(azulen-1-yl)-2,6-bis((E)-2-(thiophen-2-yl)vinyl) pyrylium perchlorate (L) was a subject of a $\mathrm{PhD}$ thesis defended in our group [20]. Similar ligands, such as 2,6-bis((E)-2(2thienyl)vinyl)-4-(4,6,8-trimethylazulen-1-yl)pyrylium perchlorate [21], have been tested and it has been shown that they exhibit complexing properties that can be used for obtaining modified electrodes for analytical applications in environmental monitoring.

*email: elena_diacu@yahoo.co.uk 


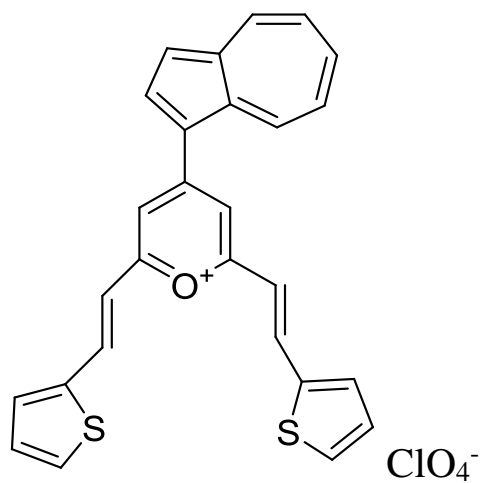

Figure 1. Chemical structure of $\mathbf{L}$

\section{Materials and methods}

$\mathbf{L}$ azulene ligand was synthesized according to the previous described method [22].

All reagents were of analytical grade. Acetonitrile (Sigma Aldrich, electronic grade $99.999 \%$ trace metals) was used as solvent, and tetra- $n$-butylammonium perchlorate (TBAP) (Fluka, puriss, electrochemical grade $>99 \%$ ) as supporting electrolyte, without further purification. Sodium acetate (Roth, 99.99\%) and acetic acid (Fluka, $>99.0 \%$, trace select) were used to prepare acetate buffer solution. For heavy metal recognition the stock solutions $\left(10^{-2} \mathrm{M}\right)$ have been obtained from lead(II) nitrate, $\mathrm{Pb}\left(\mathrm{NO}_{3}\right)_{2}$ (Sigma-Aldrich, $+99.99 \%$ trace metal basis), cadmium(II) nitrate, $\mathrm{Cd}\left(\mathrm{NO}_{3}\right)_{2} \times 4 \mathrm{H}_{2} \mathrm{O}$ (SigmaAldrich, +99.0\%), copper(II) acetate, $\mathrm{Cu}\left(\mathrm{CH}_{3} \mathrm{COO}\right)_{2} \times \mathrm{H}_{2} \mathrm{O}$ (Fluka, +99.0\%) and mercury(II) acetate, $\mathrm{Hg}\left(\mathrm{CH}_{3} \mathrm{COO}\right)_{2}$ (Sigma-Aldrich, $+99.99 \%$ trace metal basis), which were used as received, and distilled water, obtained using a Millipore Direct - Q 3UV water purification system $(18.2 \mathrm{M} \Omega \mathrm{cm})$.

The electrochemical experiments were performed at room temperature $\left(25^{\circ} \mathrm{C}\right)$ under argon atmosphere. A potentiostat PGSTAT 12 AUTOLAB was connected to a standard three-electrode cell. The working electrodes were glassy carbon disks ( $3 \mathrm{~mm}$ diameter). $\mathrm{Ag} / 10 \mathrm{mM} \mathrm{AgNO}$ in $0.1 \mathrm{M} \mathrm{TBAP}$, $\mathrm{CH}_{3} \mathrm{CN}$, was used as reference electrode, and a platinum wire served as counter-electrode. The working electrode was polished with diamond paste $(0.25 \mu \mathrm{m})$ and cleaned with the acetonitrile before each experiment.

The cyclic voltammetry (CV) experiments were performed at different scan rates between 0.1 and $1.0 \mathrm{~V} / \mathrm{s}$. Differential pulse voltammetry (DPV) was done with a scan rate of $0.01 \mathrm{~V} / \mathrm{s}$, a pulse height of $0.025 \mathrm{~V}$, and a step time of $0.2 \mathrm{~s}$. Rotating disk electrode voltammetry (RDE) experiments were recorded at $0.01 \mathrm{~V} / \mathrm{s}$ for different rotation rates.

All the potentials were referred to the potential of ferrocene/ferrocenium $(\mathrm{Fc} / \mathrm{Fc}+)$ redox couple $\left(+0.07 \mathrm{~V}\right.$ in $0.1 \mathrm{M}$ TBAP, $\left.\mathrm{CH}_{3} \mathrm{CN}\right)$ for the electrochemical study performed in organic solvent.

Electrochemical analysis of heavy metal cations detection has been done by anodic stripping voltammetry in $0.1 \mathrm{M}$ acetate buffer solution $(p \mathrm{H}=5.5)$ as supporting electrolyte. Heavy metal cation solutions of various concentrations $\left(10^{-8}-10^{-5} \mathrm{M}\right)$ were freshly prepared by successive dilutions from their $10^{-2} \mathrm{M}$ stock solutions in deionized water acquired by using a system Millipore Direct $-\mathrm{Q} 3 \mathrm{UV}$ water purification $(18.2 \mathrm{M} \Omega \mathrm{cm})$.

\section{Results and discussions}

\section{Electrochemical properties of $\mathbf{L}$}

Voltammetric experiments were carried out by CV, DPV and RDE using millimolar solutions of $\mathbf{L}$ in $0.1 \mathrm{M}$ TBAP, $\mathrm{CH}_{3} \mathrm{CN}$. All the curves were recorded starting from the equilibrium potential (the potential being scanned as indicated by arrows on all Figures).

Figure 2 shows the DPV and CV anodic and cathodic curves at various concentration $(0-2 \mathrm{mM})$ of $\mathbf{L}$ in $0.1 \mathrm{M}$ TBAP, $\mathrm{CH}_{3} \mathrm{CN}$ on glassy carbon electrode. The anodic and cathodic peaks were denoted according to the order in which they appear during the DPV scans. After the shoulder a1, which appears at about $0.85 \mathrm{~V}$, in the DPV anodic scans it can be seen two peaks (a2, a3) of oxidation, while in the DPV cathodic scans four smaller peaks $(\mathrm{c} 1-\mathrm{c} 4)$ of reduction. 
Compared to DPV, in CV curves only two main peaks are observed in the anodic scans, which correspond to the peaks a2 and a3 in DPV, and three smaller peaks, which correspond to the peaks c1, c3 and c4 in DPV, in the cathodic scans.

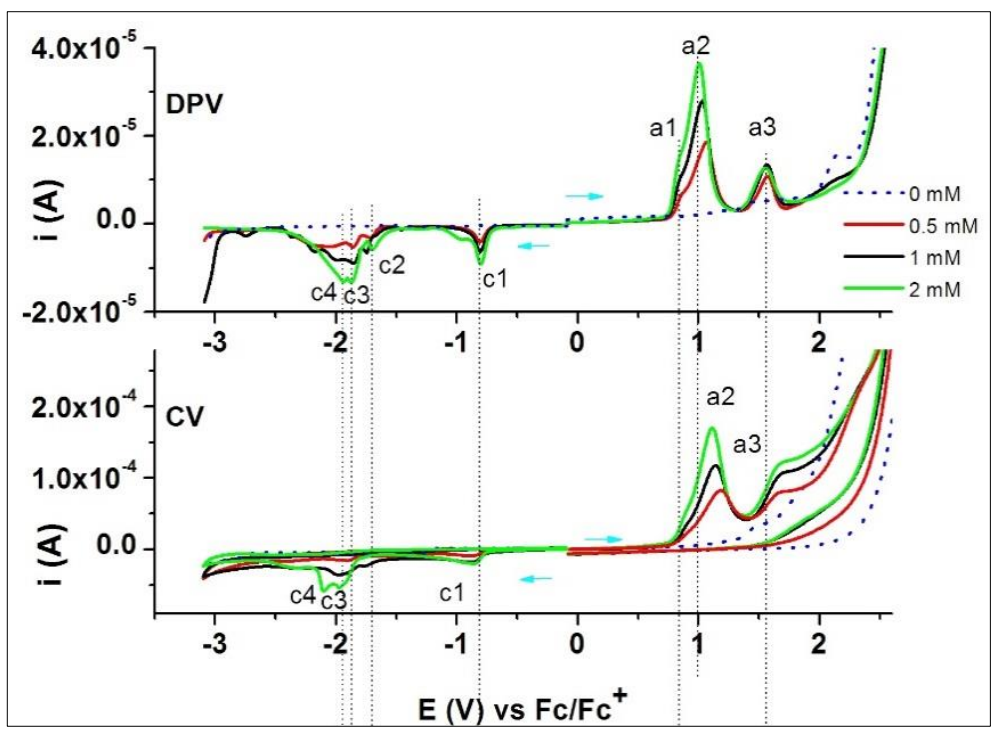

Figure 2. Studies by DPV and CV on glassy carbon electrode for different concentrations of $\mathbf{L}$ (in $0.1 \mathrm{M}$ TBAP, $\mathrm{CH}_{3} \mathrm{CN}$ )

The dependencies of the peak current $(\mu \mathrm{A}) v$ s. concentration of $\mathbf{L}$ from DPV and CV anodic and cathodic curves are represented in Figure 3. The peak currents linearly increase with concentration of $\mathbf{L}$.

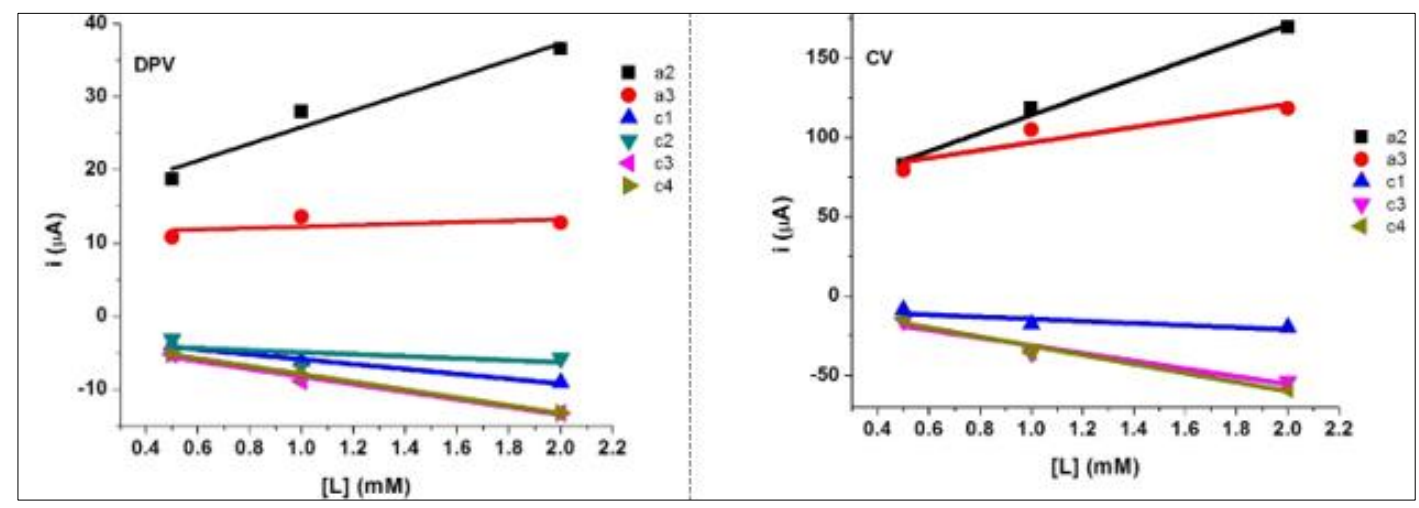

Figure 3. Dependences of anodic and cathodic peak currents $v s$. concentration of $\mathbf{L}$ from DPV and CV curves

Table 1 shows the equations of the linear dependences of the main peak currents vs. concentration of $\mathbf{L}$ shown in Figure 3 from DPV and CV. For the shoulder a1 it is difficult to estimate all characteristics in DPV and CV. For the main peak a2 the slope from CV is about 5 times bigger than that from DPV. In addition, the correlation coefficient is higher for CV than DPV. For the peak a3 the slope from CV is about 25 times bigger than that from DPV. Both correlation coefficients are small, but that for CV is higher than for DPV. For the peak c1 the absolute slope from CV is only 2 times bigger than that from DPV, and the correlation coefficient is smaller for CV than DPV. Generally, good correlation coefficients were obtained (Table 1), but the above exceptions (marked with italic letters in Table 1) appear and they will be discussed further (for the peaks a 3 and $\mathrm{c} 1$ ) in correlation with the proposed reaction schemes. 
Table 1. Equations of the peak current - i $(\mu \mathrm{A}) V S$. $\mathbf{L}$ concentration - $\mathrm{C}(\mathrm{mM})$ for the main peaks from DPV and CV

\begin{tabular}{|c|c|c|}
\hline Method & Peak & Equation (Correlation coefficient) \\
\hline \multirow{4}{*}{ DPV } & $\mathrm{a} 2$ & $\mathrm{i}=14.41+11.43 \times \mathrm{C}(0.903)$ \\
\cline { 2 - 3 } & $\mathrm{a} 3$ & $\mathrm{i}=11.25+0.99 \times \mathrm{C}(0.422)$ \\
\cline { 2 - 3 } & $\mathrm{c} 1$ & $\mathrm{i}=-2.52-3.34 \times \mathrm{C}(0.975)$ \\
\cline { 2 - 3 } & $\mathrm{c} 3$ & $\mathrm{i}=-3.01-5.21 \times \mathrm{C}(0.963)$ \\
\cline { 2 - 3 } & $\mathrm{c} 4$ & $\mathrm{i}=-2.56-5.35 \times \mathrm{C}(0.999)$ \\
\hline \multirow{4}{*}{ CV } & $\mathrm{a} 2$ & $\mathrm{i}=57.31+56.82 \times \mathrm{C}(0.984)$ \\
\cline { 2 - 3 } & $\mathrm{a} 3$ & $\mathrm{i}=72.51+24.23 \times \mathrm{C}(0.737)$ \\
\cline { 2 - 3 } & $\mathrm{c} 1$ & $\mathrm{i}=-7.65-6.64 \times \mathrm{C}(0.485)$ \\
\cline { 2 - 3 } & $\mathrm{c} 3$ & $\mathrm{i}=-6.62-24.38 \times \mathrm{C}(0.907)$ \\
\cline { 2 - 3 } & $\mathrm{c} 4$ & $\mathrm{i}=-2.63-28.61 \times \mathrm{C}(0.947)$ \\
\hline
\end{tabular}

$\mathrm{CV}$ anodic and cathodic curves at different scan rates $(0.1-1.0 \mathrm{~V} / \mathrm{s})$ for the first oxidation and reduction peaks, in $2 \mathrm{mM}$ solution of $\mathbf{L}$ in $0.1 \mathrm{M}$ TBAP, $\mathrm{CH}_{3} \mathrm{CN}$ and the linear dependencies of the peak currents $(\mu \mathrm{A}) v s$. the square root of the scan rate are shown in Figure 4. The currents in absolute values linearly increase with the square root of the scan rate for both anodic and cathodic peaks. However, the slope for a2 peak is seven times higher than the absolute slope for c1, which indicate very different mechanisms. Good correlation coefficients were obtained. The diffusion coefficient (D) of $\mathbf{L}$ was calculated using the Randles-Sevcik equation for a three electrons transfer (the reason is given further) from the slope of a2 peak vs. the square root of the scan rate, and the obtained value is $0.83 \times 10^{-5} \mathrm{~cm}^{2} / \mathrm{s}$. A close value for $\mathrm{D}\left(0.80 \times 10^{-5} \mathrm{~cm}^{2} / \mathrm{s}\right)$ was obtained when the calculation has been done from the current values of the shoulder a1 for one-electron transfer, in accord with the proposed mechanism (see further).

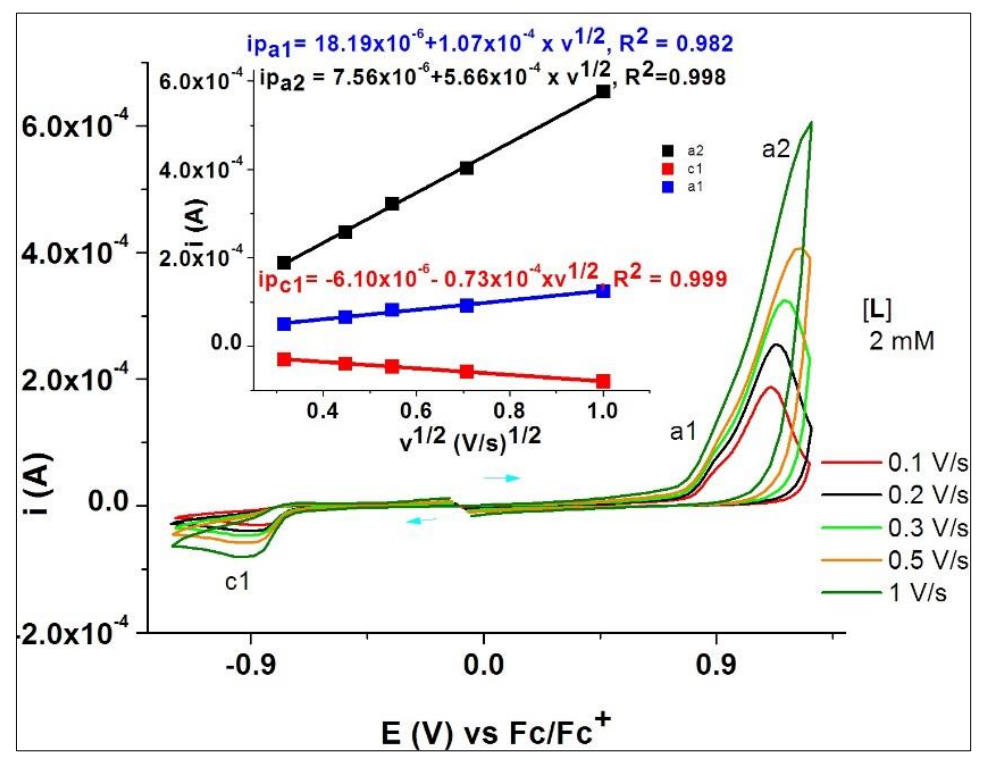

Figure 4. $\mathrm{CV}$ anodic and cathodic curves at different rotation rates $(0.1-1.0 \mathrm{~V} / \mathrm{s})$ in $2 \mathrm{mM}$ solution of $\mathbf{L}$ in $0.1 \mathrm{M}$ TBAP, $\mathrm{CH}_{3} \mathrm{CN}$; inset:

$(0.1$ the linear dependencies of the peak currents $(\mu \mathrm{A})$

( $0.2 \mathrm{vs}$. the square root of the scan rate

Figure 5 shows the $\mathrm{CV}(0.1 \mathrm{~V} / \mathrm{s})$ anodic and cathodic curves on different scan domains for $2 \mathrm{mM}$ solution of $\mathbf{L}$. In agreement with curves shapes from Figure 5 the processes c1, a2, and a3 seem to be irreversible, while the processes c3 and c4 appear more reversible (Table 2). 


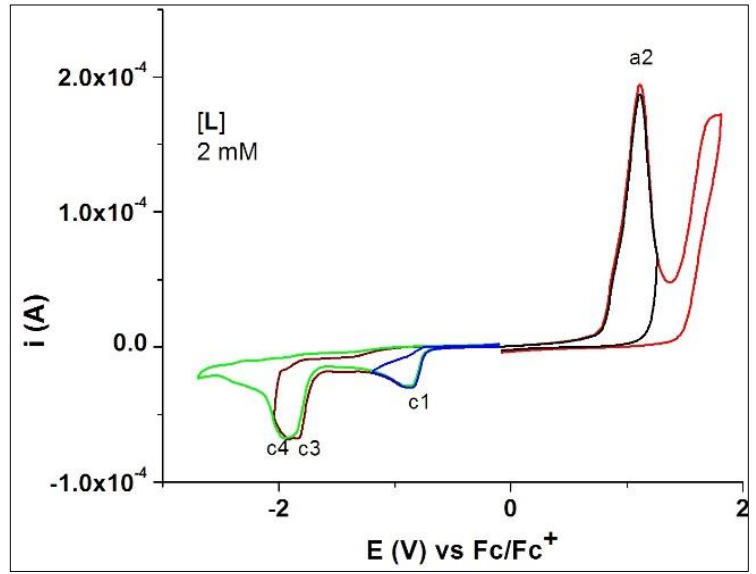

Figure 5. CV anodic and cathodic curves on different scan domains $([\mathbf{L}]=2 \mathrm{mM})$

Table 2. Peak potential values ( $\mathrm{V} v s$. $\left.\mathrm{Fc} / \mathrm{Fc}^{+}\right)$and processes from dpv and $\mathrm{CV}$ at $[\mathbf{L}]=2 \mathrm{mM}$

\begin{tabular}{|c|c|c|c|c|}
\hline \multirow{2}{*}{ Peak } & \multicolumn{2}{|c|}{ Method } & \multirow{2}{*}{ Process type } & Peak assignment* \\
\cline { 2 - 3 } a1 & $\sim 0.82$ (shoulder) & 0.86 & - & Radical-cation formation \\
\hline a2 & 1.01 & 1.11 & irreversible & $\begin{array}{c}\text { Polymer (Pa1) formation } \\
\text { Polymer (Pa1) oxidation }\end{array}$ \\
\hline a3 & 1.55 & 1.65 & irreversible & $\begin{array}{c}\text { Tridimensional polymer (Pa2) } \\
\text { formation }\end{array}$ \\
\hline c1 & -0.80 & -0.85 & irreversible & $\begin{array}{c}\text { Reduction of pyrylium cations to } \\
\text { radicals and polymer Pc1 formation }\end{array}$ \\
\hline c2 & -1.70 & - & - & $\begin{array}{c}\text { Reduction to pyran and polymer Pc3 } \\
\text { formation }\end{array}$ \\
\hline c3 & -1.93 & -1.97 & quasireversible & $\begin{array}{c}\text { Reduction to dihydropyran and polymer } \\
\text { Pc4 formation }\end{array}$ \\
\hline c4 & -1.94 & -2.27 & quasireversible & $\begin{array}{c}\text { Reduction to tetrahydropyran and } \\
\text { polymer Pc5 formation }\end{array}$ \\
\hline
\end{tabular}

*According to mechanistic Schemes 1 and 2

Figure 6 shows the RDE anodic and cathodic curves on glassy carbon electrode at different rotation rates $(500-1500 \mathrm{rpm})$ for $2 \mathrm{mM}$ solution of $\mathbf{L}$ and the corresponding DPV anodic and cathodic curves. The processes notation on the RDE curves agrees with that in DPV. In the RDE anodic scans the current initially increases, and then suddenly decreases forming a peak (in the potential domain of DPV peaks a2 and a3). The obtained curves in the oxidation domain indicate the formation of an insulating film that covers the electrode. This agrees with the fact that the rotation rate does not influence the RDE currents for $\mathrm{a} 2$ and a3. In the reduction scans an irregular RDE behaviour is also noticed in the potential domain of $\mathrm{c} 1$ (like a peak), and the rotation rate does not influence the RDE currents for $\mathrm{c} 1$, in accord with the formation of films on the electrode surface at low cathodic potentials. The behaviour becomes more regular for the other successive reduction waves (for $\mathrm{c} 2-\mathrm{c} 4$ ) for which the currents increase with the rotation rate.

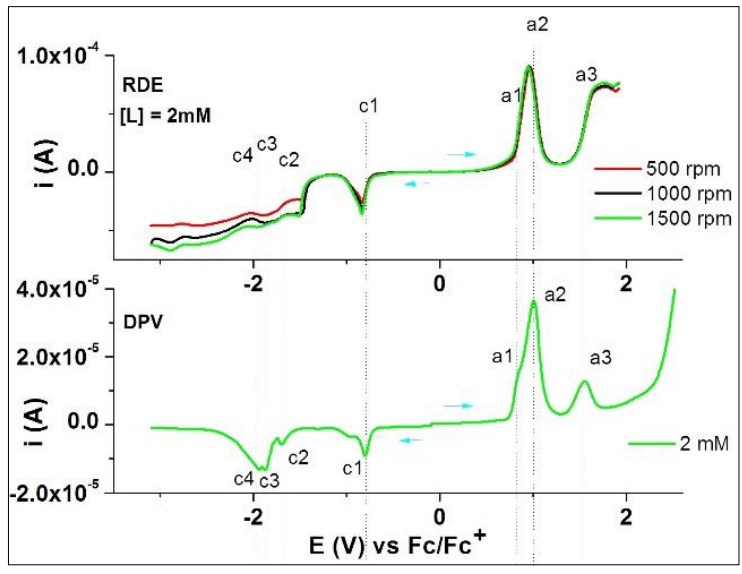

Figure 6. RDE curves at different rotation rates and DPV curves $([\mathrm{L}]=2 \mathrm{mM})$ 


\section{Mechanistic schemes}

Schemes 1 and 2 describe the most probable mechanism of oxidation and reduction for the studied compound. This agrees with the voltammetric results obtained by CV, DPV (Table 2) and RDE, and with previous investigations on the electrochemistry of pyrylium salts, which is more complex here due to the presence of several substituents. A comparison with other compounds in this class of azulenylbis(heterocyclic vinyl) pyrylium derivatives was done before, especially in [22]. Some details are given in other papers [21, 23-29].

The most probable reaction of electrochemical oxidation depicted in Scheme 1 is the formation of the radical cation of the azulene moiety $\left(\mathbf{L}^{+}\right)$, because azulene is the easiest oxidizable part of the molecule. This step could occur in the first anodic process (a1 peak). After this, another electron is lost with the formation of $\mathbf{L}^{2+}$ dication (a2 peak). This dication is reactive enough to attack, as an electrophilic species, the vinyl thiophene system with the formation of a dihydrodimer $\mathbf{D a H}_{2}{ }^{3+}$. This intermediate is not stable, and it eliminates two protons generating the dimer Da, as a double azulenic radical cation, a relatively more stable species. It oxidizes further to the azulene dications at almost the same potential with the radical cation of the monomer, increasing the intensity of a 2 peak. These cations can react in a chain with the rest of the $\mathbf{L}^{+\cdot \cdot}$ as it is depicted in Scheme 1 leading to a polymer Pa1. At higher potentials, the vinyl thienyl groups (from Pa1) can be oxidized to radical cations (a3 peak). They could react with Pa1 chain leading to a tridimensional polymer. Being a side reaction of the polymer, a low correlation coefficient of the peak a3 (Table 1) in electrochemical experiments in comparison with the other anodic peaks of the ligand could be understood.

At electrochemical reduction, depicted in Scheme 2, a pyrylium radical is formed first (peak c1 at $0.8 \mathrm{~V}$, potential characteristic for the reduction of other pyrylium salts [30]). A chemical step of dimerization of this radical to dimers, such as Dc follows, as was observed in the case of the reduction of other vinyl pyrylium salts $[23,31]$. By diprotonation of $\mathbf{D}_{\mathbf{c}}$ to $\mathbf{D} \mathbf{c H} \mathbf{2}^{2+}$ a structure that stabilizes as a bis pyrylium salt is generated, which is further reduced to diradical $\mathbf{D c H}_{2} \mathbf{2}^{-"}$ (at almost the same potential as L), leading finally to a cathodic polymer Pc1. All these processes occur at c1 peak (broad due to the simultaneous Pc1 film formation and reduction of pyrylium cations to radicals). The lower correlation coefficient of the peak c1 (Table 1) in comparison with other peaks of the ligand could be explained by this influence. The generated polymer can be again protonated leading to polymeric pyrylium salt (Pc2). The salt is reduced further at almost a similar potential as $\mathbf{L}$ (c2 peak), generating Pc3 polymer. In Pc3 the diradical has no more a 2-methylene-2H-pyran structure to be protonated to a pyrylium salt; therefore, it is reduced first to a pyran structure polymer Pc4 and then, finally, to a tetrahydropyran structure polymer Pc5. It is also possible that the pyrylium radical is involved in parallel in non-selective further reduction of the azulene and thiophene systems due to the low reducing potential differences (between peaks c2 and c3, c4).

As depicted in Schemes 1 and 2, polymer films with different structures could be formed by anodic and cathodic processes. In order to establish their real structure, characterizations are difficult to achieve, but estimates based on the number of electrons involved in these peak processes can be made. This number is higher for a 2 peak $\left(3 \mathrm{e}^{-} /(\right.$molecule of $\mathbf{L})$, than for $\mathrm{c} 1\left(2 \mathrm{e}^{-} /(\right.$molecule of $\mathbf{L})$, fact which can explain the higher absolute value for a2 slope in comparison to $\mathrm{c} 1$, in accord with the mechanisms proposed for oxidation and reduction. These influences have different slopes in CV and DPV (Table 1) due to the difference of the scan rate in CV $(100 \mathrm{mV} / \mathrm{s})$ and DPV $(10 \mathrm{mV} / \mathrm{s})$. 

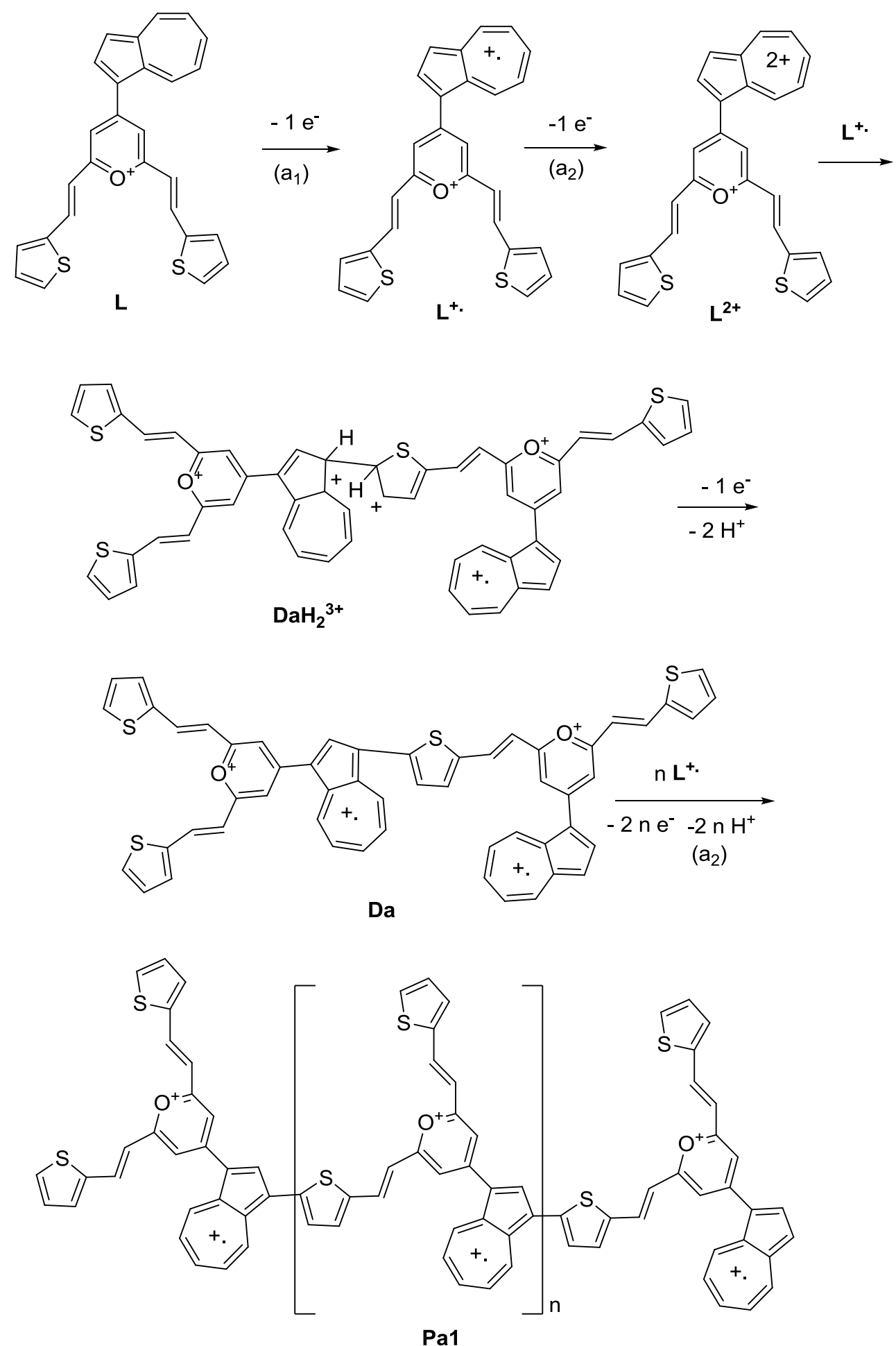

Scheme 1 


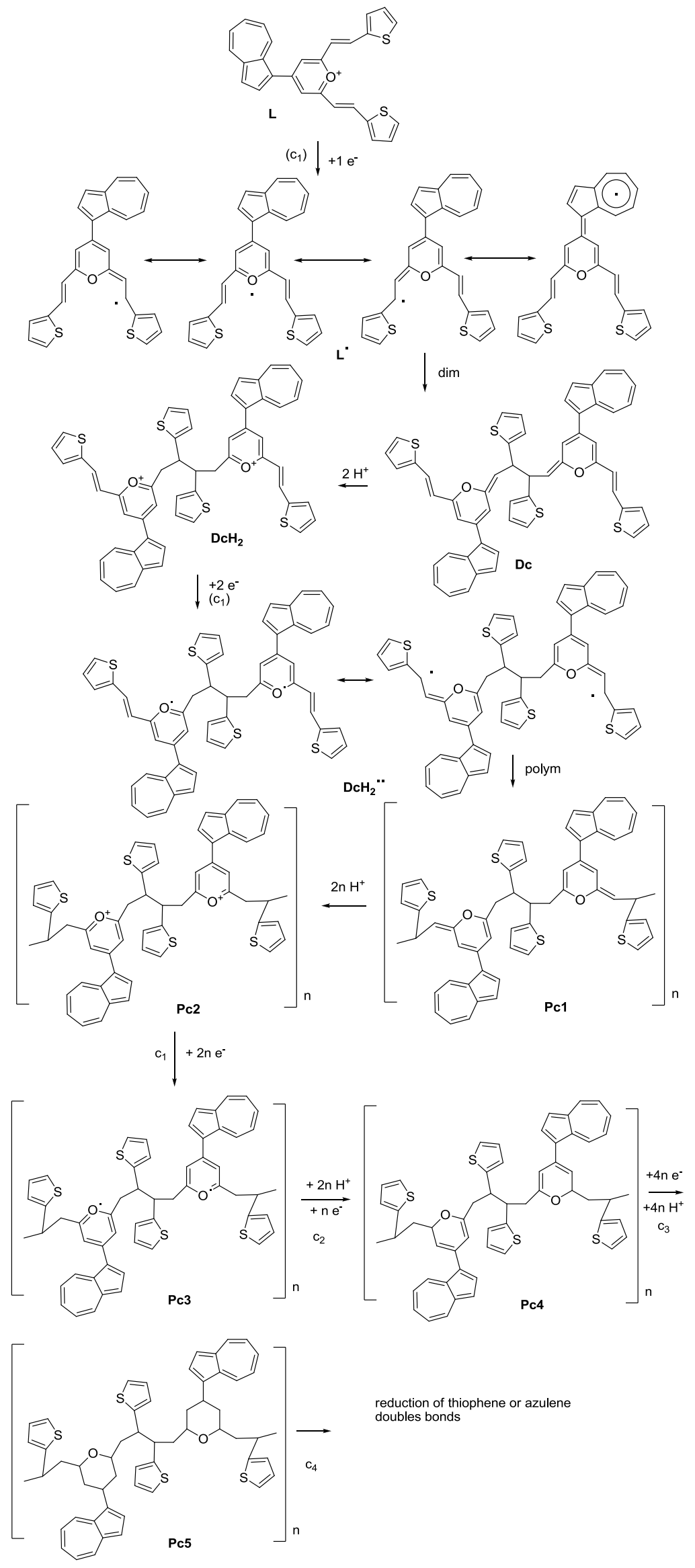

Scheme 2 


\section{Modified electrodes}

PolyL modified electrodes were prepared by successive cycling or by controlled potential electrolysis (CPE) at different electropolymerization charges in $2 \mathrm{mM}$ solution of $\mathbf{L}$ in acetonitrile containing 0.1 M TBAP. After that, the modified electrodes were transferred in $2 \mathrm{mM}$ ferrocene solution in $0.1 \mathrm{M}$ TBAP, $\mathrm{CH}_{3} \mathrm{CN}$. The ferrocene signal of the modified electrodes was compared with that obtained on bare electrode.

Figure 7A presents the CV curves obtained by 20 successive scans between $-0.2 \mathrm{~V}$ and $1.36 \mathrm{~V}$. CV curve of the corresponding modified electrode in ferrocene transfer solution is presented in Figure 7B. It can be noticed that the ferrocene signal for the modified electrode practically disappears compared to the one on bare electrode (dotted line). This means that the electrode is covered with an insulating layer.
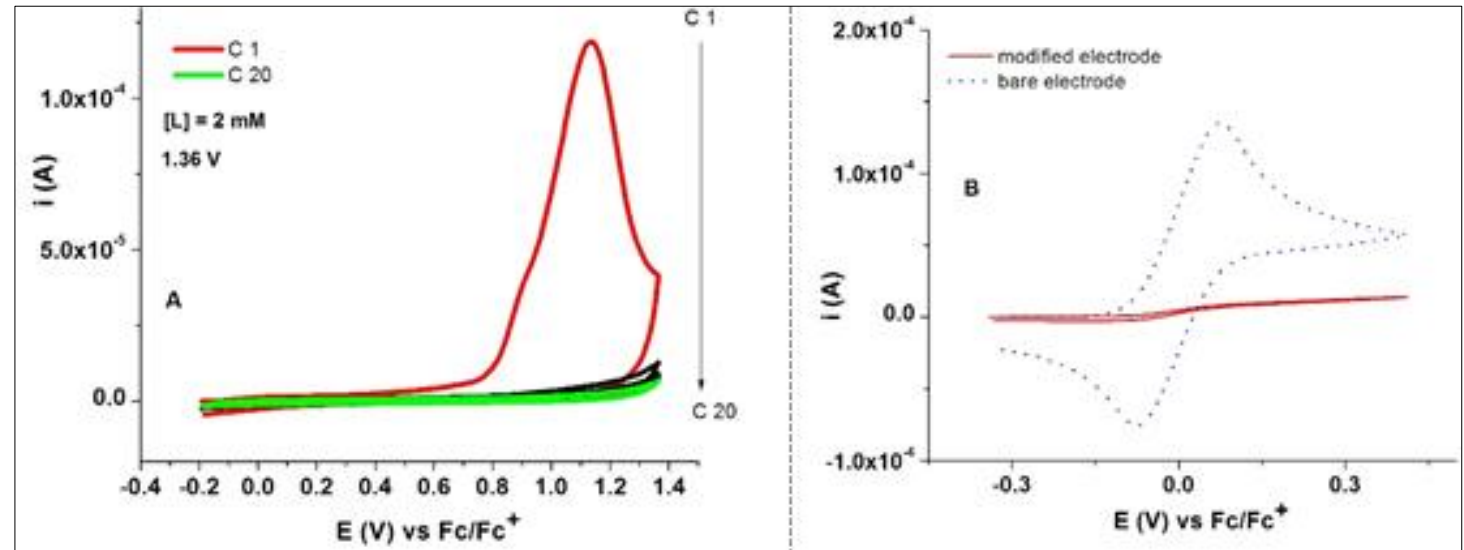

Figure 7. A - Successive CV curves in $\mathbf{L}$ solution ( $2 \mathrm{mM}$ in $0.1 \mathrm{M}$ TBAP, $\mathrm{CH}_{3} \mathrm{CN}$ ) when preparing the films by cycling the potential; B - the CV curve of the corresponding modified electrode (full line) in $2 \mathrm{mM}$ ferrocene solution in comparison with that obtained on bare electrode (dashed line)

Modified electrodes were obtained also by $\mathrm{CPE}$ at $1.36 \mathrm{~V}$ and using different electropolymerization charges $(0.36 \mathrm{mC}, 0.6 \mathrm{mC}, 0.8 \mathrm{mC}, 1 \mathrm{mC})$. Figure 8 shows the $\mathrm{CV}$ curves of the modified electrodes transferred in $2 \mathrm{mM}$ feroccene solution in $0.1 \mathrm{M}$ TBAP, $\mathrm{CH}_{3} \mathrm{CN}$. At the lowest charge $(0.36 \mathrm{mC})$ the ferrocene signal on the modified electrode is already diminished, but with the increase of the charge $(0.6$ $\mathrm{mC}<0.8 \mathrm{mC}<1 \mathrm{mC}$ ) the signal is less and less pronounced. Since a better coverage of the electrode occurs at higher charge, the poly $\mathbf{L}$ modified electrode obtained at $1.36 \mathrm{~V} 1 \mathrm{mC}$ was chosen for the recognition of the heavy metals.

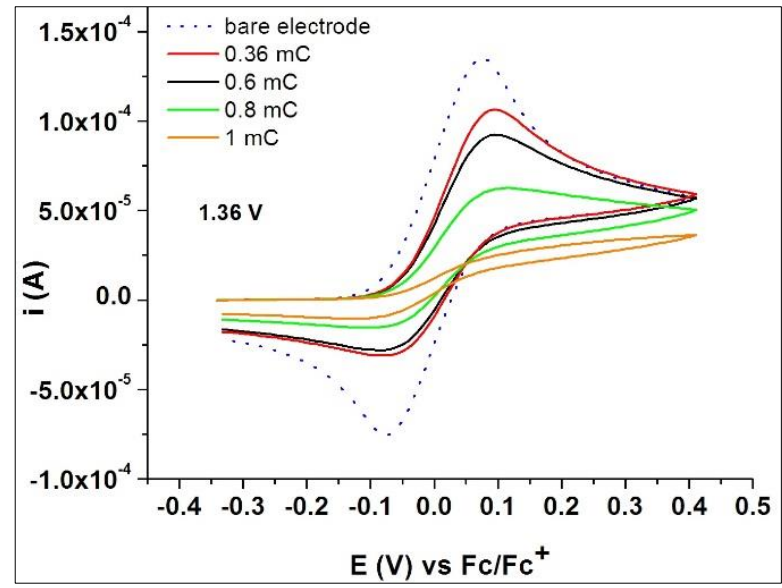

Figure 8. $\mathrm{CV}$ curves recorded in $2 \mathrm{mM}$ ferrocene solutions

(in 0.1M TBAP, $\mathrm{CH} 3 \mathrm{CN}$ ) for poly $\mathbf{L}$ modified electrodes prepared by

CPE when using different charges (at $1.36 \mathrm{~V}$ in $2 \mathrm{mM}$ solution of $\mathbf{L}$ in $0.1 \mathrm{M}$ TBAP, $\mathrm{CH}_{3} \mathrm{CN}$ ) in comparison with that on bare electrode (dashed line) 


\section{Heavy metals recognition}

Modified electrodes were obtained successively by controlled potential electrolysis (at $1.36 \mathrm{~V}$ and 1 $\mathrm{mC}$ ) in $2 \mathrm{mM}$ solutions of $\mathbf{L}$ in $0.1 \mathrm{mM}$ TBAP, $\mathrm{CH}_{3} \mathrm{CN}$. After CPE the modified electrodes were cleaned with acetonitrile and transferred in a cell containing $0.1 \mathrm{M}$ acetate buffer solution (ABS) at $p \mathrm{H}=5.5$ for equilibration and overoxidation. These steps were achieved using the CV method (10 equilibration cycles between $-0.9 \mathrm{~V}$ and $+0.6 \mathrm{~V}$ and 15 overoxidation cycles between $-0.2 \mathrm{~V}$ and $+2.5 \mathrm{~V})$. The extra treatments applied for the preparation of the modified electrodes, i.e. equilibration of the modified electrodes and overoxidation of the obtained films, lead to significant changes in the complexing properties of the modified electrodes. After the step of overoxidation, the modified electrodes were washed with deionized water and immersed in accumulation solutions containing heavy metals cations (Cd (II), $\mathrm{Pb}(\mathrm{II}), \mathrm{Cu}(\mathrm{II}), \mathrm{Hg}(\mathrm{II}))$ at different concentrations $\left(10^{-8} \mathrm{M}-10^{-5} \mathrm{M}\right)$ in water, for $15 \mathrm{~min}$. After that, the electrodes were cleaned with water and polarized for $120 \mathrm{~s}$ at $-1.2 \mathrm{~V}$ (when the accumulated cations were reduced), and then the DPV stripping curves were recorded between $-1.2 \mathrm{~V}$ and $0.8 \mathrm{~V}$ (Figure 9). DPV peaks for all investigated cations were found, at specific potentials. Figure 10A shows the dependences of these DPV stripping currents on the heavy metal ions concentrations. All the investigated cations were detected at concentrations higher then $10^{-5} \mathrm{M}$. $\mathrm{Pb}$ (II) was sensed with the highest signal. It was detected at the lowest concentrations $\left(10^{-8} \mathrm{M}-10^{-5} \mathrm{M}\right)$. Cadmium and copper were detected at higher concentrations $\left(10^{-7} \mathrm{M}-10^{-5} \mathrm{M}\right)$. Mercury is not well detected on this modified electrode. For lead, a calibration curve was obtained with a linear domain between $10^{-8} \mathrm{M}-10^{-6} \mathrm{M}$ (Figure 10B), with a good correlation coefficient (0.996). This result indicates a good sensing of lead cation when using modified electrodes based on $\mathbf{L}$. The optimization of this electrode is in progress.

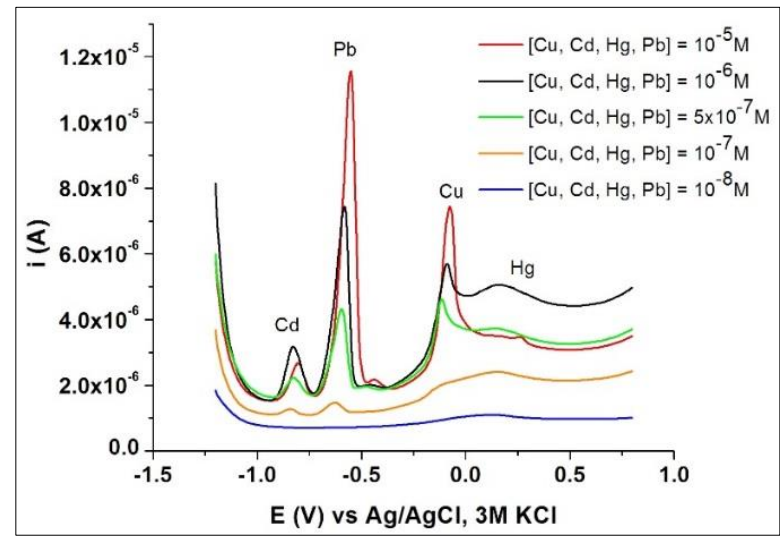

Figure 9. DPV stripping currents for the polyL modified electrodes obtained by CPE $(1.36 \mathrm{~V}, 1 \mathrm{mC})$ in $2 \mathrm{mM}$ solution of $\mathbf{L}$ in $0.1 \mathrm{M}$ TBAP,

$\mathrm{CH}_{3} \mathrm{CN}$, measured at different concentrations of heavy metals in acetate buffer solution at $p \mathrm{H} 5.5$

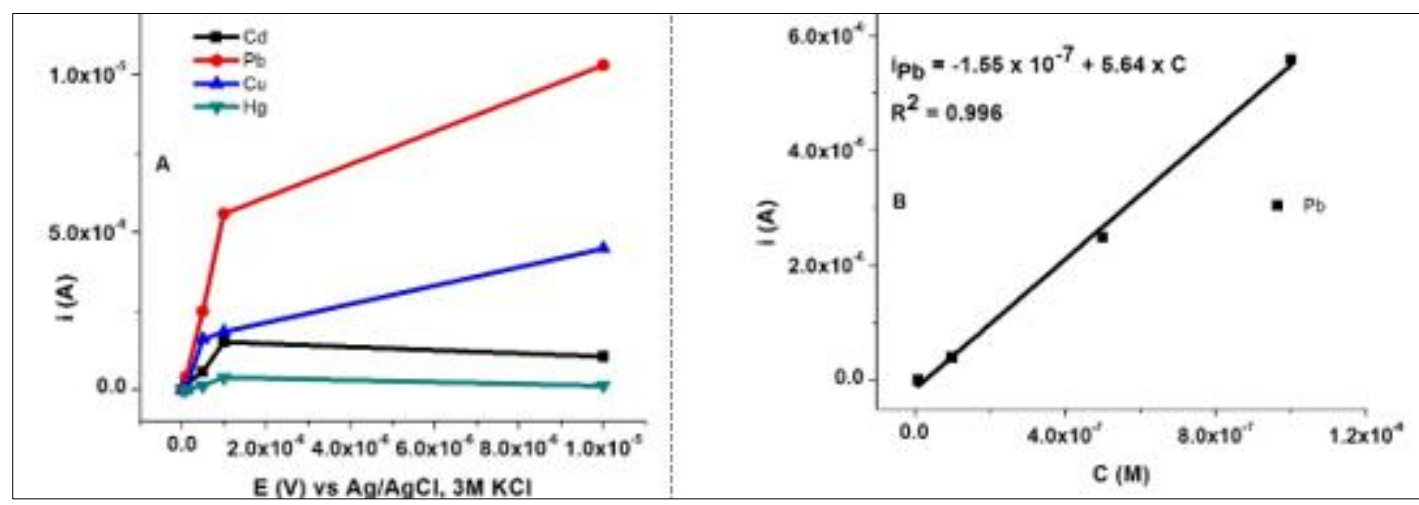

Figure 10. DPV stripping currents dependence on ions concentrations (A) for investigated metals; calibration curve for lead (B) 


\section{Conclusions}

The study of 4-(azulen-1-yl)-2,6-bis((E)-2-(thiophen-2-yl)vinyl) pyrylium perchlorate (L) was performed by electrochemical methods. The cyclic voltammetry showed the irreversible character of the polyL films formation, the differential pulse voltammetry gave the correct values of the characteristic peak potentials, while the rotating disk electrode voltammetry proved the formation of the films. Mechanistic schemes in correlation with the voltammetric results have been proposed.

Modified electrodes for metal ions complexation were obtained by successive cycling or by controlled potential electrolysis using different amounts of electricity. Sensing of heavy metal ions was tested at different concentrations of analytes $\mathrm{Cu}$ (II), $\mathrm{Pb}$ (II), Cd (II), $\mathrm{Hg}$ (II). Lead ion was detected at the lowest concentration $\left(10^{-8} \mathbf{M}\right)$. The new chemically modified electrodes based on $\mathbf{L}$ are suitable to be used as sensors for lead analysis in water.

Acknowledgements: The authors gratefully acknowledge the financial support by the Operational Programme Human Capital of the Ministry of European Funds through the Financial Agreement 51668/09.07.2019, SMIS code 124705, and Romanian National Authority for Scientific Research, UEFISCDI, under grant PN-III-P1-1.1-TE-2016-0860 contract no. 114/2018, and INTELMAT 39 PCCDI -2018.

\section{References}

1. RAZUS, A.C., BIRZAN, L., CRISTIAN, S., CHIRALEU, L.F., CIMPEANU, V., Dyes and Pigments, 57, 2003, p. 223.

2. RAZUS, A.C., BIRZAN, L., CRISTEA, M., TECUCEANU, V., HANGANU, A., ENACHE, C., Journal of Heterocyclic Chemistry, 48, 2011, p. 1019.

3. RAZUS, A.C., NICA, S., CRISTIAN, L., RAICOPOL, M., BIRZAN, L., DRAGU, A.E., Dyes and Pigments, 91, 2011, p. 55.

4. UNGUREANU, E.-M., BUICA, G.-O., RAZUS, A.C., BIRZAN, L., WEISZ, R., BUJDUVEANU, M.-R., Rev. Chim., 63(1), 2012, 27.

5. UNGUREANU, E.-M., CRETU, M.-S., BUICA, G.-O., RAZUS, A., BIRZAN, L., Electrochimica Acta, 53, 2008, p. 7089.

6. LACROIX, P.G., MALFANT, I., IFTIME, G., RAZUS, A., NAKATANI, K., DELAIRE, A., A Chemistry European Journal, 6, 2000, p. 2599.

7. YAO, J., CAI, Z., LIU, Z., YU, C., LUO, H., YANG, Y., YANG, S., ZHANG, G., ZHANG, D., Macromolecules, 48, 2015, p. 2039.

8. SMITS, E.C.P., SETAYESH, S., ANTHOPOULOS, T.D., BUECHEL, M., NIJSSEN, W., COEHOORN, R., BLOM, P.W.M., DE BOER, B., DE LEEUW, D.M., Advanced Materials, 19, no. 5, 2007, p. 734.

9. NISHIMURA, H., ISHIDA, N., SHIMAZAKI, A., WAKAMIYA, A., SAEKI, A., SCOTT, L.T., MURATA, Y., Journal of the American Chemical Society, 137, 2015, p. 15656.

10. XIN, H., GE, C., YANG, X., GAO, H., YANG, X., GAO, X., Chemical Science, 7, 2016, p. 6701.

11. STADLER, R., Nano Letters, 15, no. 11, 2015, p. 7175.

12. BIRZAN, L., CRISTEA, M., DRAGHICI, C., TECUCEANU, V., MAGANU, M., HANGANU, A., ARNOLD, G.-L., UNGUREANU, E.-M., RAZUS, A.C., Tetrahedron, 72, 2016, p. 2316

13. LAZAR, I.G., DIACU, E., VASILE, G.G., UNGUREANU, E.M., IVANOV, A.A., Rev. Chim., 69(9), 2018, 2311.

14. VASILE, G.G., ARNOLD, G.L., BUICA, G.O., DIACU, E., UNGUREANU, E.M., DINU, C., Rev. Chim., 69(1), 2018, 21.

15. CRISTIAN, L., NICA, S., PAVEL, O.D., MIHAILCIUC, C., ALMASAN, V., COMAN, S.M., HARDACRE, C., PARVULESCU, V.I., Catalysis Science and Technology, 3, 2013, p. 2646.

16. BUICA, G.O., UNGUREANU, E.-M., BIRZAN, L., RAZUS, A.C., MANDOC (POPESCU), L.R., Journal of Electroanalytical Chemistry, 693, 2013, p. 67. 
17. BUICA, G.-O., IVANOV, A.A., LAZAR, I.-G., TATU ARNOLD, G.-L., OMOCEA, C., BIRZAN, L., UNGUREANU, E.-M., Journal of Electroanalytical Chemistry, 849, 2019, DOI: 10.1016/j.jelechem.2019.113351.

18. BUICA, G.-O., BIRZAN, L., TECUCEANU, V., RAZUS, A.C., ARNOLD, G.-L., UNGUREANU, E.-M., Electroanalysis, 29, 2017, p. 93.

19. BUICA, G.-O., LAZAR, I.-G., BIRZAN, L., LETE, C., PRODANA, M., ENACHESCU, M., TECUCEANU, V., STOIAN, A.B., UNGUREANU, E.-M., Electrochimica Acta, 263, 2018, p. 382. 20. LAZAR, I.-G., University Politehnica of Bucharest, 2018, PhD Thesis.

21. LAZAR, I.G., DIACU, E., ARNOLD, G.-L., UNGUREANU, E.-M., BUICA, G.-O., BIRZAN, L., Bulgarian Chemical Communications, 49, 2017, p. 227.

22. BIRZAN, L., CRISTEA, M., DRAGHICI, C.C., TECUCEANU, T., HANGANU, A.M., UNGUREANU, E.-M., RAZUS, A.C., Tetrahedron, 73, 2017, p. 2488.

23. OUÉDRAOGO, J. C.W., TAPSOBA, I., GUEL, B., SIÉ SIB F., BONZI-COULIBALY, Y. L., Bull. Chem. Soc. Ethiop., 27, no. 1, 2013, p. 117.

24. BA, F., CABON, N., POUL LE, P., KAHLAL, S., SAILlARD, J.-Y., PO

UL LE, N., GOLHEN, S., CARO, B., ROBIN-LE GUEN, F., New J. Chem., 37, 2013, p. 2066.

25. BERBEROVA, N.T., DOROFEENKO, G. N, OKHLOBYSTIN, O.YU., Chem. Heterocyc. Compd., 13, 1977, p. 250.

26. GARRARD, FK.N.C., THOMAS, F.G., Aust. J. Chem., 40, 1987, p 579.

27. PRAGST, F., ZIEBIG, R., SEYDEWITZ, U., DRIESEL, G., Electrochim. Acta, 25, 1980, p. 341

28. PRASAD, N., MAIN, L., NICHOLSON, B.K., McADAM, C.J., J. Organomet. Chem., 695, 2010, p. 1961.

29.TOTIKOV, M.G., ARUTYUNYANTS, A.A., BUMBER, A.A., IGNATENKO, E.L., OKHLOBYSTIN, O. Y., Chem. Heterocyc. Compd., 26, 1990, p. 393.

30. SAEVA, F.D., OLIN, G.R., J. Am. Chem. Soc., 102, 1980, p. 299.

31. BERBEROVA, N.T., DOROFEENKO, G.N., OKHLOBYSTIN, O.Yu. Khim. Geterotsikl. Soedin. 3, 1977, p. 318 (p. 250 Engl) 